\title{
Study on New Media of College Students' Party Building Work
}

\author{
Zhixue Wang ${ }^{1, \text { a }}$ \\ ${ }^{1}$ Higher Education Research Institute, Jilin Agricultural University, Changchun, China , 130118 \\ ${ }^{a}$ email
}

Keywords: New Media, Universities, Party Building Work, Students, Wechat

\begin{abstract}
With the development of digital technology, network technology, mobile communication technology, new media has changed the way of life of college students also bring unprecedented opportunities and challenges to the traditional building in college students. New Media on College Students Party values, education and school party building authority members have an impact, to fully explore and utilize the positive effect of new media on College Students' party building work, open up new ideas, to build a new platform to expand education of party building support to enhance Party Building educational effectiveness.
\end{abstract}

\section{Introduction}

New Media (New Media) concept by the US Columbus graduation broadcast networks (CBS) The Gold Mark (P.Gold Mark) 1967 first proposed the. He believes that the new media is the new media or new media are new media, is the integration of audio and video text messages, new media, that is to narrow the technological innovation of traditional media, the concept of formal innovation and innovation.

Our scholars generally believe that the new media is the new media forms with respect to the press, radio, television and other traditional media to raise is a relatively broad concept that refers to the new technical support system appear under the media forms, the use of digital technology, network technology mobile communications technology and other channels, through computers, mobile phones, digital television and other terminal to provide users with communication pattern information and entertainment services. Strictly speaking, the new media should be referred to the new digital media.

The difference between new media and traditional media is not that time has appeared, but the mode of transmission and content of different forms. The spread of new media has the following characteristics:

Traditional media information release has a strict "editing" and "three trial" system, the release of the contents of the selection information to you strictly. In the new media era, everyone can participate in the dissemination of information in the past, new media low threshold, easy to operate, just after a simple registration and user information registration, anyone can edit the information yourself, information dissemination, information dissemination the whole process in the new media era, everyone has the microphone, everyone is a news agency, everyone is a spokesman. For this kind of personal information, civilians, Cape generalization, independent of the spread of this openness, also contributed to the growing number of so-called "self-media" or "citizen media" This new media forms and shapes.

Traditional media information is the single, linear propagation, this form of many, so that the public dissemination of passive acceptance, no interaction communicator and the recipient. Compared to traditional media, new media in the dissemination process among the acceptor and information sources frequent, extensive and rapid interaction, this interaction may also be a two-way multi-directional, we take the phone to see the video, read the news we can message directly into the community to discuss such a news, to discuss such a content, it is the traditional interactive media do not have.

Production and the production cycle of the traditional media information is very long, and the new media restrictions based on Internet technology and mobile communications technology, independent of time and space, can send and receive information at any time, move the new media 
age, the Internet information dissemination of new media than Times more simple and convenient. Compared with traditional media, new media can spread text, music, pictures, video and other richer information than traditional media, new media, the amount of information carried by exponentially grow exponentially.

\section{The Challenges of the New Media to Bring the Building in College Students}

Recently released "New Media Blue Book: China New Media Development Report No.5 (2014)", a book outlining the current situation of China's new media development, an inventory of the mobile Internet, micro-channel, microblogging, big data and cloud computing, social media, triple play, broadband China, smart city and things, mobile application App, OTT TV and other top ten hot spots, the researchers note: microblogging, micro-channel, micro-video and other mobile Internet-based micro applications popular, has become the mainstream mode of transmission, and is rapidly extended to the government and other areas constitute the 2014 China new media development "micro era" landscape.

College students are the most active users of new media, new media, widely used college students to obtain a wealth of information, but also highlight Students pursue self, individuality, fresh adventures characteristics with respect to the Party Building in Colleges and Universities under the traditional media environment is very different, new media to carry out the political construction of University Students' Party, the ideological construction, organization construction, style construction, system construction, and discipline and so brought a profound impact and challenges.

Review and constraints "gatekeeper" role in the new media era of information dissemination weakening, a lot of bad information, and Western neo-liberalism, ideology and other historical nihilism and utilitarianism, egoism, money, values and social doctrine and other bad ideas, new "mainstream media" voice media platform for the dissemination of a variety of different voices from all sides of the network, to carry forward the socialist core values gradually weakened, college party members no longer accept being a "unified voice" told right or wrong, how to deal with individual and collective interests, conflict of national interests, everyone is independent from the information obtained, to judge things, university students Party easily blind conformity, deviation is generated false information to mislead, confuse, cognition, lack of reason and proper analysis, the lack of political experience and theoretical knowledge of the communist faith into question, resulting in a strong impact on the Student Member of values.

The traditional college student party member education students were identified as the development object, through lectures, reports, newspaper to convey document separate conversation, now into the floor to the representative group activities, payment of learning materials and other party members to carry out educational activities, these methods have the time and site constraints, the effect of education is limited, and this indoctrination and spoon-feeding education is very boring, ineffective, low attractiveness. New media is not limited in time and space, spread wide, spread contains rich text, pictures, sound, video and other content, interactive, traditional education of Party members of college students posed a challenge.

Party Building in Colleges traditional media environment, through the campus network, campus radio, newspaper, campus video news and other mainstream media, publicize the party's principles and policies, the latest theory, advanced deeds and other party members, campus radio, newspapers, billboards and so on campus media information published by the issuer to the validation of university information, publisher of information with absolute information release authority. To strengthen the ideological construction of university student grassroots party organizations through the official voice of traditional media, organizational building, work style, anti-corruption, institution building, as the College Students' Party managers, the use of traditional media not only determines the release of information the amount of content, quality, flow and direction, but also directly determines the role and impact of the information the party's grassroots construction.

In the new media environment, release and use of time and space related party building information and resources are more free, the recipient of each message can be disseminators of 
information, the information will be received in the shortest possible time through a variety of ways spread, they can be published through the micro-channel, microblogging, easecredit, flying letters and other information, or even with the official information to the contrary or Universities odds information and can spread quickly and produce mass effect on campus. Thus it greatly shortens the distance information between the publisher and the recipient, and both transposition in the communication process, such as "civilian" "grassroots" of the identity of the post, to a certain extent weakening the authority of the official release party.

\section{The Building in College Students to Explore New Media}

Colleges shoulder cultivate qualified builders and successors of socialism sacred mission, college students Party members are college students excellent groups, colleges and universities to carry out grassroots party building is to use advanced theory and advanced thought of the Student Member of the mind, take the initiative to conquer new media Party Construction strengthen party building new media propaganda, firmly grasp the impact of the use of new media, information and education initiative of party members, party members so that the majority of students come to understand the socialist core values and deep identification with the socialist core values and "China dream" to lead the students in the pursuit of ideals, to realize the value of life during the depth practice, continue to be translated into concrete action on the growth of learning to do to achieve excellent results, good style, thought up, moral, healthy personality, culture grown to a patriotic, dedicated, honest, College Students' Friendly value guidelines.

Party in college managers to build a new platform for media education of Party members, members of educational resources using rich new media provided to university students loved the way images, video, video and other resources to carry out education of Party members, more interesting and interactive learning content, clear new the direction of media education of Party members, the use of new media, the spread of Marxist theory, to strengthen the national policies of public education in a timely manner to educate students on social hot spots and focus, in terms of ideology highlight the main theme for the mainstream ideology to carry out positive guidance, boycott of Western social awareness and value of diversity of impact, so that students from poor external interference phenomena and ideas, build a strong ideological line of defense, to address national problems of social development, and guide students to establish a correct outlook on life and values. Rich socialist core values education new carrier, so full of vitality of socialist core values. To train young members of the social responsibility of students, national consciousness, human feelings, the scientific spirit, good feeling and good will.

With the new media platform, built on the traditional branch network, the traditional activities of the organization in the form of a single branch, mostly in the form of meeting conduct, organizational development, in the form of branch selection, etc. to carry out organizational life, weak organization, lack of energy, and these activities are limited by time and space, and colleges and universities in different professional practice and social practice time is difficult to unity, high grades in school graduation practice is difficult to participate in branch activities. Branch activities through the motions, a mere formality, and enhanced spirit cultivating intellectual exchange activities, in-depth criticism and self-criticism is relatively small.

New Media in networking and communications technology as the basis, to break the constraints of time, Party building in universities can integrate new media resources, the establishment of new media linkage system, such as: "party online learning site, branch Weibo, members of the family micro-channel group, SCHOOL micro-channel public platform "and so on, to create a new branch activities and management, to make up for lack of traditional branch through new media, between teachers and students, the exchange between old and new members can be exempted from the limitations of time and space, go practice and practice students can participate in branch activities and organizational life, greatly enriched the forms of education of Party members and branch activities, content and tools, with the new media, greatly mobilized the student branch members to participate in the activities of enthusiasm, participation and initiative.

Manpower advantage of traditional branch and new branch management, comprehensive use of 
interactivity, convenience and openness of the traditional strengths and new branch Party branch. Strengthen the integration and sharing of resources, the establishment of the new branch by the new media can be a co-management model teachers and students, student members through new media and the old and new members and teachers exchange and discuss, learn from each other, exchange views and enhance the Party a variety of resources to participate in the construction branch of interests and abilities, teachers and students can be members for party members to study through new media publishing.

New media age, microblogging, everyone, flying letters, QQ and so was all the rage, college students become mainstream social platform, "2014 micro-channel user behavior analysis report" shows that the micro-channel user activity students is higher than the activity of other users , 78 percent of college students who use the micro-channel frequency in excess of microblogging, everyone, QQ mobile phones and any other social software.

Since the foundation micro letter is a communication tool, chat software, acquaintances community, dating platform features and zero tariffs, cross-platform, timeliness, mobility, interactivity, quick, experience, diversity, information and large beyond other social advantage software, social software has become the mainstream of current students.

Micro-channel platform as the current coverage, users, and more convenient operation of the new media, to subvert the traditional mode of transmission media, so that the dissemination of information more quickly and effectively. Party in college education managers should grasp the opportunity to establish a micro-channel-based, supplemented by other new media, "a multi-master auxiliary" party platform. In micro-channel structures of our Party platform, based on micro-channel spread fast, wide coverage, anytime access to information and other advantages functions by sending maps, text, sound, like the party building information and Mao, increasing party transparency, and promote Party building work information, make Party building in Universities spread of micro-channel platform has become the voice of the party an important window to understand the dynamics of students Party members convenient channels to enhance effective carrier College grassroots organizations, services, an important platform for students of party members,

Through micro-channel platform to promote its party building the Party's line, principles and policies, ideological lead and guide public opinion, to pass positive energy, strengthen the Party's sound propagation and penetration, sing the main theme, boost Manner, to stimulate positive energy, positive with a positive voice and advanced culture occupy the position, build a strong "firewall."

Workers Party in college to focus into the micro-channel platform and Student Member of the interaction and cross

On the stream, the utterance involved in interaction and communication and sound transmission, so that the micro-channel platform audience, influential, echo, with "micro" platforms boost "big" party, so that the "small and micro letter" play "big as a" use "micro-education" adaptation "micro era."

\section{References}

[1] Zheng Xiaoyi. Explore relying microblogging Innovation of University Students' Party [J]. Fujian Radio \& TV University, 2011 (01).

[2] Liu Xiaodan. Interst. Challenge and Countermeasures under the new media background College Students' Party faces [J]. Education of 2014 (04).

[3] Wu Yong. Ways of Ideological and Political Education in the New Media Age Innovation [J]. School Party and ideological education, 2012 (05).

[4] Zhao Yang. innovation in the new media Political and Ideological Education of College Students' Thinking [J]. Ideological Education Research, 2011 (12). 